\title{
THE SILVER OF THE GODS On Old Assyrian ikribū
}

\section{Jan-Gerrit DERCKSEN}

Silver, gold and rarely copper destined for Assur, as well as merchandise brought from Assur to Anatolia, are sometimes identified as $i k r i b \bar{u}$. In the singular, the word means "blessing, benediction" and "votive offering" in Old Assyrian. It is derived from the verb karābum, "to pray, to pledge." The plural $i k r i b \bar{u}$ is translated "money or goods pledged by a vow to a deity" in CAD I/J [1960], 64a, where on page 66 follows "The plural form (ikribu) denotes both a prayer and (in $O A$ and $O B$ only) a votive offering pledged to a deity in a specific prayer. These offerings (money, cultic objects and merchandise) were sometimes of little value (especially in $\mathrm{OB}$ ), sometimes, however, they comprised large amounts (especially in $\mathrm{OA}$ ). The latter were set aside for reasons which we cannot clearly establish, possibly to let the deity share in

1. Also used for "malediction", e.g. in AKT 3, 63: 13 and KTS 15: 25. Compare 1.L. Finkel, Hul.ba.zi.zi; Ancient Mesopotamian Exorcistic Incantations (Ph. D. thesis University of Birmingham 1976), 272.

2. This verb occurs in $\mathrm{Pa} .10$ (=L 29-563): ${ }^{17} \ldots 6$ ma-na ${ }^{18} \mathrm{~KB}$ a-na ${ }^{\mathrm{d}}$ IYtar ${ }^{19}{ }_{i-n a}$ li-bi ${ }_{4} i k-r i-b i_{2}-a{ }^{20} b i_{4}$-lam su-ma lá ma-şi $2 l_{i-n a}$ ra-mi-ni-kà $22 i-d i ́ . ~ a-n a$

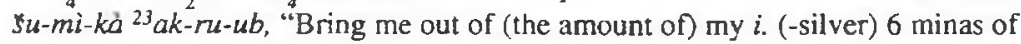
silver for Istar; add some of your own (silver) if (this amount) should be insufficient; I promised it for you." Hirsch (UAR, 24 and 28), renders it "Um deinetwillen(?) habe ich gebetet." It is also used in the meaning "to give as a present", often of small amounts of silver and sometimes in a religious context,

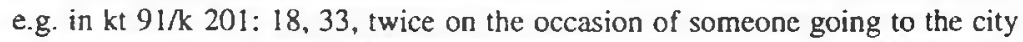
of Assur. This use of karäbum resembles that of the verb naqā'um "to sacrifice", and of niq 'um, used for making gifts as well.

3. See A. Skaist, The Old Babylonian Loan Contract [1994], 172-179 with literature, for $i k r i b \bar{u}$ in $\mathrm{OB}$ texts. The otherwise unattested feminine plural form ikribätum occurs in ARM 23, 561: 15 (or táq'-ri-ba-tim?), cf. the copy by P. Villard in MARI 6. 598. 
the business undertaking and thus to insure its success" ${ }^{3}$ Von Soden (AHw 370a) rendered it "Weihgaben" while referring to $\mathrm{H}$. Hirsch, $U A R, 60 f$. According to Hirsch, the $i$. are partly votive offerings to a god, of which the person making the offering can dispose; he rejects the idea that a repayment of a temple-loan is meant, as suggested by Lewy (see below). Ikribū ("ikribum") would be closely related to the word niq'um, "offering", and perhaps even subordinated to it $(U A R, 61)$.

A different view was taken by J. Lewy, who interpreted the word commercially, and wrote in 1957: “ikribü denotes capital advanced by a temple administration to a businessman and goods as well as certain profits obtained with such funds." ${ }^{4}$ P. Garelli ${ }^{5}$, M.T. Larsen ${ }^{6}$, and K.R. Veenhof, followed this interpretation of $i$. as goods advanced by a temple, which it had originally obtained as votive offerings. In WZKM 62 [1969], 52, Hirsch wrote that $i$. includes also money entrusted to merchants by a temple. Garelli ("Ce sont des biens voués à une divinité.") considered it likely that the merchants themselves earmarked part of their income as a votive offering. Such payments could have formed a guarantee fund, with which the temple was able to provide financial assistance to people in need. In general, a temple would have used its capital commercially. A merchant was free to use the $i$. as he wished, but he possessed it only for a limited period of time. Veenhof added a different consideration on the advantage for the temple itself: "The temples took part in the trade by entrusting to merchants goods produced by the temple or bought with temple money ( $i k r i b u \bar{u})$; they may have wanted in return silver and gold for their treasuries and for display purposes." It would concern a long term investment ${ }^{8}$.

4. OrNS 26,19 note 2.

5. $A C, 252-257$.

6. $A O C C, 149$.

7. AOATT, note 466 .

8. Iraq 39 [1977], 114. 
The consensus seems to be that Old Assyrian $i$. denotes a type of commercial loan or investment, provided by a temple (as is attested for Babylonia) to a merchant. The plural of "votive offering" is used because the money or the goods bought with it, originate from offerings (in silver or gold) made to the temple; it underlines that the "loan" consisting of such goods remains sacred. The absence of any debate in recent scientific literature might suggest that all has already been said and written on this subject. Still, the numerous references justify a renewed scrutiny of the evidence, in which we fell encouraged by a remark made by M.T. Larsen (AOCC, note 126).

\section{The ikribü-system in practice}

No document is available at present, detailing how or why an $i$. was obtained from a god's temple. We find that only individuals or families held an $i$. Several small texts record the borrowing of $i$. silver. $\mathrm{Kt} \mathrm{d} / \mathrm{k} 3$ and $\mathrm{kt} \mathrm{m} / \mathrm{k} \mathrm{116}$, for example, are anonymous memoranda recording a debt of silver (being) $i$. of Assur". The dating by hamustum- eponym(s) shows the transaction took place in Kanish. Both documents mention the addition of "interest" (15\% and $131 / 3 \%$ per year), apparently from the moment the silver was borrowed. The structural similarity and the fact that no creditor is mentioned, might suggest that this silver was not borrowed from a private person, but from an organisation, like the temple of Assur in Kanish. However, one should rather regard these texts as ordinary loan documents recording the borrowing of silver belonging to the $i$. of Assur, held by another person. The amounts of silver borrowed in $\mathrm{kt} \mathrm{d} / \mathrm{k} 3$ and $\mathrm{kt} \mathrm{m} / \mathrm{k} 116$ are relatively small, but compare $\mathrm{kt} \mathrm{a} / \mathrm{k} 495 \mathrm{~b}$ where 20 shekels of silver belonging to the $i$. of Assur held by Puzur-Ana had been given as a tadmiqtum-loan. The rate of interest is only half that of the usual $30 \%$ sanctioned by the kārum. This attractive rate of ca. $15 \%$ occurs in at least five

9. $\mathrm{Kt} \mathrm{d} / \mathrm{k}$ 3: 30 shekels of silver, i.sa Assur; $\mathrm{kt} \mathrm{m} / \mathrm{k}$ 116: 24 shekels of refined silver, $\xi_{a}$ i.ła Ał̧ur. There seems to be no practical difference between silver that is " $i$. of A" and "part of the $i$. of A". 
other loans, all with Enlil-bānì as creditor ${ }^{10}$. They all involve default payment (šmma lā isqul...), except for TC 3, 213: 40, which, like the two $i$. texts, does not mention a term for repayment. The reason is unclear why Enlil-ban1 charged this rate in these texts. The background for these loans at a moderate rate of interest is unknown. As K.R. Veenhof points out ${ }^{11}$, the severe consequences of bankruptcy, for the debtor as well as for his creditors, led to procedures aimed at reducing the risk of a trader really going bankrupt. Financial help could be given in the form of temple loans and private financial arrangements (e.g. AKT 1,61). The concept of the temple as financial helper of needy persons occurs in for instance Garelli's discussion of $i$. (see above). The ambiguity of the two $i$. texts makes it impossible to determine whether interest was charged by the temples. If that was the case, it is possible that all persons listed in Appendix $\mathrm{B}$ as $i$.- holders received the loan at a moderate rate of interest, but it is perhaps too bold to assert that they were experiencing financial difficulties when turning to the god.

10. See Garelli, AC, 380-383. These texts are: EL $47=$ KTS 45b; EL $225+C C T 1$, 4:11, 34; TC 3, 213: 40; OIP 27, 59: 51.

11. Personal communication; see also his remarks on the expression sa balätisu in AOATT, 363-364. For the procedures according to the mediaeval Geniza documents, sec S.D. Goitein, A Mediterranean Sociefy, Volume 1: Economic Foundations, 204: "If, however, through acts of God or through his own fault, a merchant found himself unable to meet his commitments, his fellow merchants, as a rule, would come to his assistance and prevent his becoming bankrupt. (...) Such help was extended in many different ways, loans of capital or goods, without interest of course, being the most frequent form. In cases of insolvency, the authorities and more prominent members of the community intervened and arranged for a settlement, mostly acceptance of payment in installments of small sums over a long term. In more serious cases, one-third of the debt was remitted, another third paid in cash, and for the remaining third payment in installments promised. When things got to their worst, namely when, after the declaration of bankruptcy, the person concemed was unable to make the payments agreed upon in the settlement, the communal authorities would assemble the more affluent merchants who would then make contributions in cash. The declaration of bankruptcy, or "oath of destitution, "would be admitted only after approval by the highest communal authorities." 
Another small text is kt $876 \mathrm{k} 38$, which $\mathrm{K}$. Hecker will publish. It records that the anonymous writer will "remit" 45 shekels of silver, $i$. of Assur, ina suhuppim. The meaning seems to be that the writer will repay his $i$ - loan at the suhuppum (in Kanish), the creditor being perhaps the temple of Assur. Should its organisation or facilities be inadequate to handle such financial transactions, then the kārum- office with its authorities and warehouse (suhuppum) offers itself as a competent alternative. The details which $K$. Balkan ${ }^{12}$ gave from text $\mathrm{kt} b / \mathrm{k} 499$ suggest that the debt mentioned there of $1 / 3$ mina of gold to the kärum (8ff: "I owe $1 / 3$ mina of gold to the Colony (of Kanis)") is the same as the $i$ loan mentioned in line 10f. (ikribū mala tuppi armam ukallu), because a debt in gold to the kârum is very rare. Gold belonging to the god Adad was (at times) collected at the kārum- office according to AnOr $6,16^{13}$. The suhuppum appears as the place where the loan was repaid, and probably also where it was obtained.

The $i$ - holder could freely dispose of the Ioan. Silver from an i. - was frequently given as a tadmiqtum- loan (e.g. to Assur-nādā in $\mathrm{kt} \mathrm{a} / \mathrm{k}$ 495b). Debts could arise when $i$.- goods were given to a business partner. ICK 2, 113, deals with the settling of affairs between Il1-banı and the son of the deceased Puzur-ili, after which the latter's children and creditors take an oath that they will not claim anything from Il1-banit ${ }^{14}$ Lines 6-10 enumerate some of the ways Ilī-bānì might have become indebted: the ebuttum- and tadmiqtum- loans represent special financial arrangements, while the phrase "or every shekel of silver he owes" describes more common ways a debt was incurred. The last alternative, "or connected with (the) $i$., " refers to a debt as well.

12. Kanišsuwar, 2 note 4.

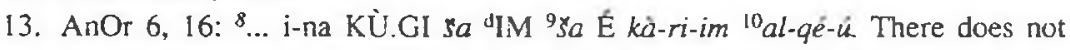
seem to be a suhuppum of Adad; the $\langle\zeta a>$ added by the editors in KTS 2, 9: 57 , is unnecessary, cf. Kh. Nashef, WdO 25 [1993], 167.

14. ICK 2, 113: ${ }^{6}[\mathrm{lu}]$ AN.NA a-na e-bu-tim ${ }^{7}[1]-d i-s u-u m$ lu KB 1 GÍN $^{8} i$-șe-ri-su. i-su ${ }^{9}\left[l u\right.$ t]a-ad-mi-iq-tám ${ }^{10}[i]-d i-s u-u m ~ l u$ ła ik-ri-bi "[mi]-ma a-wa-ti-su-nu ${ }^{12}[n]-i-i g-m u-u r-m a$. 
One has to look at the value of merchandise or at the amounts of silver and gold sent as proceeds to Assur to obtain some insight into the size of an $i$. held by a merchant. A glance at Appendix A reveals that the amounts of silver and gold sent as $i$. vary greatly. A nepisum-package containing 11 minas of silver is attested in KTS $9 \mathrm{~b}: 8-9$, and one with 15 minas in CCT 1, 16b: 4-5 $5^{15}$. Attested transports of gold, for which an exchange ratio of 1: 7 was normal in Assur, consist of 3 minas (in kt e/k 37 twice, and once $25 / 6$ minas). An amount of 110 minas of fine copper (worth less than 2 minas of silver), is mentioned in LB $1220 .^{16}$ The data on the volume of merchandise obtained with $i$. in Assur show considerable differences as well. Tin usually was added to a caravan-load in a separate package (riksum) containing 7 minas (AKT 3, 65: 8-10), 9 minas 29 shekels (BIN 4, 51: 5-6), 15 minas (KTS 21b: 20-22; VS $26,65: 40$ ), or $34 / 1 / 3$ minas (BIN 4, 51:7). Only Pa. 13 with 1 talent shows a more substantial quantity of tin. The number of textiles varies as well, from one or a few, 4 (out of a transport of 206, CCT 5, 36a: 3), 40 (out of a transport of 210, kt c/k 454: 13), a transport of 82 (Medelhavsmusett 1977/12: 20-21), and even of 299 textiles (out of a transport of 342 , JCS 14 no 4: 12-13). These goods were entrusted to agents who exchanged them for silver and gold, like any other merchandise, or were deposited at the kārum-office (e.g. in kt 91/k 329) ${ }^{17}$. The proceeds were sent to Assur, often to be converted into merchandise again. Gold is used for instance in CCT 2, 32a: 21-22: "Buy for me tin for the (half a mina of) gold of my $i$."; silver for instance in $\mathrm{kt} \mathrm{c} / \mathrm{k}$ 528: 17-19,

15. This text lists a number of nêpisum and riksum packages with silver destined for several persons in Assur in lines 1-18. Only lines 19-22 are concerned with niq'um- "offerings," which shows Hirsch's equation of $i$. with niq'um (UAR, 61 ), to be incorrect. EL I 124, discussed on the same page, mentions 3 different posts.

16. LB 1220: 5.... 1 GÚ 50 ma-na ${ }^{6}$ URUDU SIG ${ }_{5}$ a $i k-r i-b i_{4}-a \ldots{ }^{12} 1$ ma-na KÜ.KI

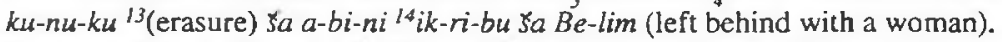

17. In $\mathrm{kt} \mathrm{n} / \mathrm{k}$ 510: $9^{\prime}-11$ and $16^{\prime}-18^{\prime}$ ', the kärum "released" an additional (DIRI) 1 mina $7 / 1 / 2$ shekels of silver "because of your $i$." A possible interpretation is that the kārum (unexpectedly) sold part of the trader's $i$. goods he had given to it; it seems less likely that it refers to a disbursement to an $i$. - holder. 
where 30 minas of refined silver plus 1 mina of $i$ age given to a merchant ana siamatim, "for making purchases". But compare kt $\mathrm{n} / \mathrm{k} 210$, where Ilabrat-banı asks Ușur-sa-Istar to exchange the gold of his $i$. for silver and send it to Assur, so that merchandise (simum) may reach him. Copper obtained by exchanging $i$. goods was sent to Assur, e.g. in BIN 4, 113 (=EL 261); presumably also the 20 minas of fine copper, $i$. of Bēlum, sent to Assur and mentioned in CCT 2, 36a: 9-10. In ICK 2, 89, 11 minas of fine copper, $i$. of Aššur, were destined for Šmat-Aššur. Perhaps one has to read " 30 !" instead of " 3 " minas of fine copper in TC 2, 54: 8'.

The amount of $i$. metal transported to the capital was not necessarily obtained by selling merchandise labelled as $i$. According to KTS 27b, Salim-ahum orders Püsu-kēn to add silver to a transport, while the latter is requested to add gold in TC $2,4^{19}$. An inscription on the clay bulla attached on the package with silver or gold identified the contents as being $i^{20}$ The consignment mentioned in KTS $27 \mathrm{~b}$ has to be identified as $i$. in the list recording the caravan's cargo to avoid paying saddu'atum, as the text adds. The expression "(silver/gold) will go for (the loan of) the $i . "$ (ana (ša) $i k r i b \bar{i}$ illak) means the amount was earmarked for use as $i{ }^{21}$ Alāhum, the sender of $\mathrm{kt} \mathrm{c} / \mathrm{k} 50$, ends this letter by informing the

18. Hirsch. UAR note 265 , argues that this amount represents an offering to the deity.

19. KTS 27b: ${ }^{3} \ldots a-s e^{2}-e r^{4} 5 m a-n a$ KB ša $a-n a{ }^{5}$ dNIN.ŠUBUR-ba-ni ${ }^{6} a^{3}-p u-r u$ is $a-t a{ }^{7} 10$ ma-na i-na KB-pi-a ${ }^{8}$ ra-di-ma 15 ma-na ${ }^{9} \mathrm{~KB}$ is KÜ.GI ${ }^{10}$ ma-la tù-ba-lá-ni "i-na a-wi-tim ${ }^{12}$ ša ILLAT-tim ki-ma KÙ.[BA]BBAR ${ }^{i j i k-r i-b u-n i}$ ${ }^{14} \mathrm{wa}$-dí-ma, "You must add 10 minas from my silver to the 5 minas about which I wrote to lllabrat-bânĩ, and (as for) the 15 minas of silver or gold, as much as you bring me, indicate in the list recording the value of the caravan that the silver is $i$." (collated by P. Garelli, Fs. L. Matous I, 124 note 37); TC 2, 4: 18/1/3 ma-na KÙ.GI i-na K[Ü.GI-si-a] ${ }^{19}$ ra-di-ma is-té-ni-is 1 ma-na ${ }^{20} \mathrm{KU}$.GI $a-n a$ ik-ri-bai-a ${ }^{21} \mathrm{ku}$-un-kam-ma, "(Make a debtor pay $2 / 3$ mina of gold and) add 1/3 mina from my gold, and put in all 1 mina of gold destined for my $i$, under seal."

20. RA 59 no 24: ${ }^{7} i k$-ri-bu sa 13 -ha-ra ${ }^{8} p a ́-n u-s ̌ u-<n u>$ lá-áp-tù, "On their surface is written: ' $i$. of Ishara."'

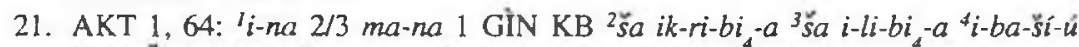

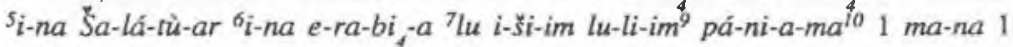


addressesees that the silver and gold one of them sent to him, has been destined for $i$; now he asks to send the silver and whatever else has been obtained in exchange for the merchandise he had apparently bought with $\mathrm{it}^{22}$.

Goods belonging to an $i$. were subject to several taxes and charges. The nishatum (levied in Assur at a merchant's office) and saddu'atum (a fee paid to the transporter) were added to transports of silver and gold sent as $i$. from Anatolia ${ }^{23}$, but are sometimes omitted $^{24}$. Larsen's remark appears to be correct that "both taxes obviously had to be paid" when the money was sent for making purchases $^{25}$, although the gold mentioned in KTS $27 \mathrm{~b}$ may have been stored for some time in the temple (see below), and might even be used to pay back the loan. There is an exceptional passage from KTS 27b: 12-16 (see note 19), where a transport of silver and gold will be exempted from šaddu'atum en route if it is labelled $i^{26}$ A rare case of compound nishatum (nishät nishätim) on $i$. silver occurs in CCT 1, 16b: 7. ${ }^{27}$

Textiles bouht in Assur were taxed for dātum and in Kanish for nishätum according to $\mathrm{kt} 87 / \mathrm{k} 459$. During the clearing at the

$1 / 2$ GíN KB a-na sal ${ }^{2} i k-r i-b i_{4} a{ }^{13} i-l a ́-a k$, "By means of the 41 shekels of silver of my $i$. which I owe (=still have to pay) as well as with the proceeds of the luli 'um-mineral, 1 mina 1 1/2 shekel of silver will immediately go (be added to) the amount of my $i$. as soon as I enter Salatuar." Note that the amount to be sent as $i$. to Assur is $50 \%$ higher than that of the $i$ - debt.

22. Kt c/k 50: ${ }^{33} \mathrm{~KB}$ ú KUं.GI ša A-šur-be-el-SA-TU ${ }^{34} \dot{u}$-šé-bi-lá-ni a-na ik-ri-bi

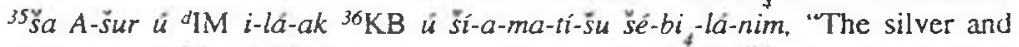
gold which Ašsur-bêl-sadue sent me will go to the i. of Aššrur and Adad. Send me the silver and what you bought with it!"

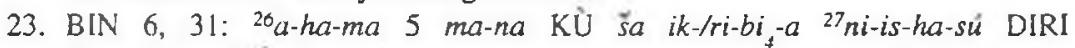
$[k u-n u]-k i-a{ }^{28} s a-d u-a-s u \hat{~}$ sa-bu (buy $[\ldots]$ for it); CCT 2, 32a: ${ }^{7} . .1 / 2$ ma-na

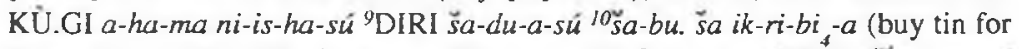

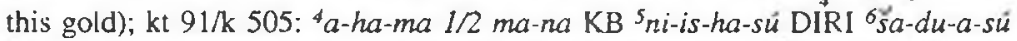
sa-bu (for making purchases); TC 3,68: $3 \ldots 1$ ma-na KÙ.GI * pása-lam $n i-i s-h a-s u ́$ DIRI ku-nu-ki-a ${ }^{s} i k-r i-b u s a$ sa-sur (store it in the temple).

24. Kt c/k 528: ${ }^{14} \ldots 30$ ma-na KB ${ }^{15}$ sa-ra-pá-am ni-is-ha-sú DIRI ${ }^{1 \sigma_{s}}$-du-a-sú ša-bu ú a-ha-ma ${ }^{17} 1$ ma-na sa ik-ri-bi-a.

25. Larsen, $O A C P$, note 44.

26. See Larsen, $O A C P, 88$ (waddi-ma).

27. See Larsen, $O A C P, 119$ with note 58. 
palace in Kanish, the nishatum-tax (5/120) was levied on $i$. textiles, but they were sometimes exempted from the tithe (išrätum, a privilege of the local ruler to pre-empt 10 per cent of the textiles),

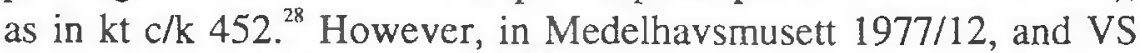
26,150 , both išrātum and nishătum were levied on $i$. textiles. ${ }^{29}$ In the first text, the proceeds from the išrătum on the $i$. were booked on the owners account (qätum) at the kärum-office (lines 39-43); a similar result is ultimately obtained in $\mathrm{kt} \mathrm{c} / \mathrm{k} 452$, where $3 \mathrm{i}$, textiles $(=10 \%)$ are deposited on the owner's acount (qatum) of the kārum-office (lines 19-21). The remainder of the textiles, including those of the $i$., was brought to Purušhattum, where the metum hamsat- tax of 5 per cent was levied on the whole transport. This suggests the $i$. textiles were normally subjected to the išra $\bar{a} t u m$, be it directly or indirectly. The evidence demonstrates that specific advantages for $i$. concerning taxes or levies did not exist.

The special nature of the goods made it a sacrilege for non-Assyrians to confiscate it; the ruler of Zalpa is told: "You cannot hold the god's $i . ! " 30$ The Assyrian House of the City (bēt alim) could take $i$. goods as a security when their owner or his heirs did not pay a debt. Silver of an $i$. might even be used to repay a debt to the bett älim in Assur: "And the $i$. silver which I brought here with my transport has been paid as far as necessary to the bet alim for your father's debt. We bought textiles for the rest of the silver, but the limmum- eponym has laid a claim on it.",

28. Kt c/k 452 (125 entered the palace; $61 / 4$ taken as nishâtum; $301 / 2$ textiles of the $i$. they did not charge for the tithe, išratim lâ ulammidū). Compare $\mathrm{kt} \mathrm{c} / \mathrm{k}$ 454 ( 210 entered the palace; ca. 10 taken as nishătum; the remaining $200 \mathrm{left}$ the palace): ${ }^{\prime 0} \ldots$ i-na $" 12$ me-at TÚG.HI-ri-kis sa i-na ${ }^{2}$ É.GAL-lim ur-du-ni-ni ${ }^{13} 40$ TÚG.HI.A $\zeta a$ ik-ri-bi ${ }_{4}-k \grave{u}{ }^{14}{ }^{4} u$-ša-bi ${ }_{4}$-ma ša me-at 60 TÚG.HI.A ${ }^{15} 16$ TUGG.HI.A is-ra-tim, 13-14: "I statisfied (the palace) concerning the 40 textiles of your $i . "$

29. Medelhavsmuseet 1977/12: 82 textiles were brought by Uzua; 5 are "mine", 8 išrātum; 4 nisbātum; 6 losses; rest: 59 textiles. VS 26, 150: 39 textiles; 2 nishātum; $35 / 6$ išrätum.

30. TC 3. 85: ${ }^{22} \ldots$ um-ma ${ }^{23} n e ́-n u-m a ~ i k-r i-b i$ ša i-lim ${ }^{24} l a ́$ tù-ká-al.

31. Kt n/k 531: ${ }^{7} \ldots$ ù KB ša ik-ri-bi ${ }^{8}$ ša i-na šé-pí-a ${ }^{9} a-n i-i s ̌-a-n i \mathrm{~KB}{ }^{10}$ ša ša-qá-lim.

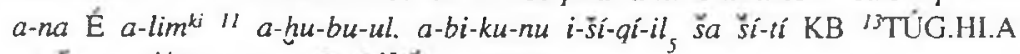

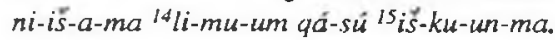


In JCS 14 no 4, a quantity of 299 textiles "of $i$. " is mentioned. If bought at $31 / 2$ shekels a piece, they would have cost $171 / 2$ minas of silver; if sold at 10 shekels, the yield would have been 50 minas. Apparently not only the $171 / 2$ minas, but these 50 minas would be called $i$. when sent to Assur. The term then encompasses not only the original amount received from the temple, but the profit realised with it as well. As direct evidence is lacking, we can only speculate about the destination of the silver and gold. It is stated in AKT 1, 64 (see note 21) that the silver to be sent to Assur will consist of the $i$.debt plus $50 \%$, but it is unclear to which degree this single reference is representative of a system. Apart from this text, there are no signs that the profit was possibly handed over to the temple when the proceeds arrived in Assur; on the contrary, it seems the whole sum was used preferably to make purchases again. Apparently the merchant, while enjoying certain advantages (low rate of interest also in Assur?) connected with the long term $i$ - loan during which he increased its value, had upon termination of the $i$. to pay back only the original amount. Part of the profit, however, he was expected to devote to the presentation of votive offerings. This emerges from letters sent by Aššur-iddi (n), where he orders the manufacture of a gold sun disc he owes to Assur, by using $i$. silver ${ }^{32}$. In kt 89/k 226 and 432, the expressions kasap ikribē ša mazzāzim ša Aššur (kt 89/k 226: 10-12) and copper sa ikribí ša Aššur ša mazzāzim (kt 89/k 432: 1-4), might refer to the donation to the deity agreed upon when receiving the $i$. -loan. Contrary to Hirsch, ${ }^{33}$ the word mazzäzum hardly means "security"

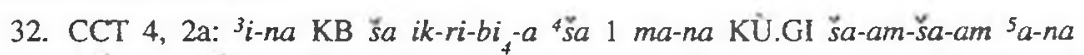
$A$-šur e-ep-ša-am, "Use silver of my $i$. to make for me a sun-disc of 1 mina of gold for Aššur." Also in Pa. 10: ${ }^{13 \breve{s} a-a m-s ̌ a-a m . ~ s ̆ a ~}{ }^{14} 1$ ma-na KÙ.GI ${ }^{15} a-n a$ $A$-šur $e$-ep-ša-am, "Use silver of my $i$. to make for me a sun-disc of 1 mina of gold for Aššur." Also in Pa. 10: ${ }^{13}$ sa-am-ša-am.sa ${ }^{14} \mathrm{I}$ ma-na KÙ.GI ${ }^{15} a-n a$ A-šrur ha-bu-lá-ku ${ }^{1 \sigma_{i}-n a ~} i k-r i-b i_{4}-a{ }^{17} e p-s ̌ a-a m$. But compare Hirsch, who, in his discussion of $\mathrm{Pa} .10$ ( $\mathrm{L} \mathrm{29-563)}$ (UAR, 24), points out that this debt does not necessarily include the $i$. BIN 6,30 has in lines 24-26: $\grave{u}^{24} s^{u} u$-ma $\grave{u}$-rù-ra-ú ${ }^{25} i$-š $i$-si $a-q e_{5}-e r-b i$-ma ${ }^{26} i$-di, "And if there is anything in excess, include it in (the package)." One expects the first word in line 25 to be $i$-ba- $\xi_{i}-u$.

33. Hirsch, Akkadisch (altassyrisch) mazzāzum "Pfand, Verpfändung", WZKM 62 [1969], 52-61. 
in these texts, but rather statuettes. This emerges from kt $89 / \mathrm{k} 226$ (which will be published shortly by Y. Kawasaki), containing a reference to five small statuettes which were to be brought into the temple $^{34}$. The passage from ICK 2, 157 where this word occurs as well, describes how the valuable property of a deceased father falls to the (eldest) son, while the duty and perhaps financial burden of bringing his votive offerings into the temple will be shared by $\mathrm{all}^{35}$. The failure to fulfil the financial aspects of this religious obligation led to divine anger, see below ${ }^{36}$.

\section{The duration}

The references from texts concerning decease and inheritance to be discussed below clearly demonstrate that an $i$. was a long-term obligation. It did not end with the holder's life, to be returned after his death. On the contrary, it usually was passed on to his wife and children, similarly to the inheritance of assets in a trader's naruqqum- capital. ${ }^{37}$ Examples are the cases of Ilī-bānī (ICK 1, 12), Elamma (kt 91/k), and Aššr-imittī (kt n/k). The wish to end an $i$. apparently was announced by the divine owner himself. In some cases, this came about by what were considered to be signals, like the ilness reported in KTS 25 a (see below). In others, the repayment might be conditioned by rules unknown to us, if the passage from ICK 1,12 is interpreted correctly (see below with

34. Kt 89/k 226: ${ }^{16} \ldots 5$ ma-za-ze-e ${ }^{17}$ sa i-le-e. șa-hu-ru-tim ${ }^{18}$ lu nu-šé-ri-ib.

35. ICK 2, 157: ${ }^{2 \prime}$... ša A-šùr-ma-lik a-ḩu-ú-šu $22 u ́$-lá tá-h̆u-ú a-šu-mi ma-za-zi ${ }^{23} i k$-ri-bi ša a-bi-šu ú-šé-ru-bu "(All money either in Assur on in Anatolia, which La-qeep left behind when he died) is for Ašsur-malik; his brothers have no right to aything. As for the statuettes, the $i$. of his father, they (all) will bring (them into the temple)". A totally different interpretation of this passage was given by Hirsch, WZKM 62, 59-60.

36. M. Stol, JEOL 32 [1991-1992], 46: "We add that the Diagnostic Handbook [= $T D P]$, in the few cases it mentions human $\sin$, has a marked interest in illicit sexual contacts (...) and in not fulfilling vows made to the gods (ikribu. kaspu)".

37. For example the assets Pǘru-kēn possessed in several naruqqu's were inherited by his children; cf. Larsen, Iraq 39, 141 with note 76. 
note 60$)$. Kt $\mathrm{n} / \mathrm{k} 516$ is a letter from Lä-qēp to Ašsur-takläku, Nab-Suen, Assur-malik and Enna-Suen. The sender writes to Nab-Suen about his distress because the latter has not sent him their father's $i$. of Assur. Their father apparently had died and his $i$. had to be repaid; but the cause for repayment is unknown ${ }^{38}$.

The verb erābum $\check{\mathrm{S}}$, used when for instance a votive offering is brought into a temple, occurs also when money from an $i$-loan is brought there. Śalim-ahum asks his son Dān-Ašsur to send (the) silver of his $i$. according to AKT 3,73 and 74. In the last letter, he adds: "I will bring my $i$. in (the temple) when the silver arrives; it will not be used for making pruchases" ${ }^{39}$ One might consider this to mean that Salim-ahum wishes to terminate this $i$. by returning it to the temple. However, the silver and gold of an $i$. could be brought into a temple without ending the financial relationship, as is illustrated by two texts. The first is the letter TC 3,68, which has been treated by Hirsch*. The writer, Enlil-bānī, instructs the addressees in Assur how to act when Kukulānum brings them a package (riksum) with 1 mina of pašallum gold, $i$. of Assur. They must bring the package with gold into the temple of Ašur and ask the priest (kumrum) for the bag (naruqqum) in which Enlil-bānī's sealed packages are stored. Then they are to check the seal impressions on the bag and open it and place the package with gold (presumably in the bag) a-na tí-ri be-e-li-im. Enlil-bānì is aware that this may cause trouble, and the addressees are begged to keep it secret from his relative (mahä'um) Ašsur-lamassi ${ }^{-41}$. We find here that part of the Assur temple was used to store silver and gold under the seals of their owners. The text does not mention whether

38. Kt n/k 516: ${ }^{8} \mathrm{~KB}$ ik-ri-bu. ša a-bi-ni ${ }^{9}$ ša $A$-šùr mi-šL-um lá tù-šé-bi-il "oli-ba-am. lá ta-dí-nam "ù na-pá-ấs-tí-ni. la té-te ser, "Why did you not sent the silver of our father's $i$. of Assur, and so failed to encourage me and save us?"

39. AKT 3, 74: ${ }^{36} \mathrm{~KB}$ i-lá-kam-ma ik-ri-bi ${ }_{a}-a{ }^{37}$ ú-sé-ra-ab ${ }^{38} a-n a$ ši-a-ma-tim ú-lá $i-t \grave{u}-a r$.

40. UAR, 23 note 114. Change the transcription in line 14: i-de $e_{g}$; 18: [Ku-ku-la]-nim; 19: [ri-ik]-sà-am; 21: ku-[nu-ki].

41. See BIN 4, 68: 5, a letter written to Ab-šalim, probably Enlil-bänỉ's sister. 
the other packages in the bag contained silver or gold of $i$. as well. The expression left untranslated remains without parallel. Hirsch tentatively rendered it "legt das Bündel Gold zum tiri (sc. tiri-Silber?) des Bēlum." Perhaps not the god Bēlum, but bëlum, "the possessor (of the $i$.)" is meant, and one has to interpret the expression as an administrative term describing the status of this package with $i$. gold ("for the $\operatorname{tur}(i)$ of the possessor") ${ }^{42}$. It might involve the $i$. holder reserving the right to take the gold out again in future. The other text is a letter to Innayya by his son Ašsur-taklāku (kt 87/k 34). A package with $i$. silver of Innāya, stored in a temple (bët ilim, probably the temple, i.e. that of Ašsur in the capital) among the packages of a colleague, has to be deposited with Innaya's other packages. Also this text demonstrates the role of the temple as a place for safe-keeping. The silver and gold stored there appear to be still in the possession of the merchants, who could take some of it out when necessary. One would like to know whether only $i$. silver and gold were stored there, or whether it served as a general storage place as well ${ }^{43}$. In RA 59 no 5, packages with silver and copper are enumerated which were entrusted to Puzur-Ašsur and destined for Wawali. Lines 8-12 read: "1 package with 15 shekels, $i$. of Šarra-mātēn; 10 shekels for the storeroom; 20 minas of copper, $i$. of Bēlum. "44 These packages were evidently meant to be brougt to Assur, and Wawali might use the silver and copper as money. The "storeroom" as destination refers to the storing of the package with 10 shekels. The context of this passage makes it likely that this amount is also related to an $i$.loan, and the storeroom is then perhaps not in a private house. This qarab-bëtim might denote here a temple storeroom, similar to the

42. Bêl ikribi may denote the (divine) owner (see note 45), but also the holder (though not yet attested, neither is mukit i.). Compare M. Roth, AV E. Reiner, 363 , for the semantic ambivalence of belum.

43. See the remarks by K. van der Toom in his book Family Religion in Babylonia, Syria and lsrael (Leiden 1996), 34: "There was hardly a safer place to put one's money than the temple treasury: the god himself would kep watch; embezzlement would amount to hierosylia."

44. RA 59, 5: ${ }^{8} 1$ ri-ik-sú 15 GÍN 9ik-ri-bu ša Šar-ma-té-en ${ }_{6} 10$ GÍN a-qá-ra-be-tim "20 ma-na URUDU ik-ri-bu sa Be-lim. 
one where silver and gold were stored according to TC 3, 68 and $\mathrm{kt}$ $87 / \mathrm{k}^{34}$.

\section{The owners}

The nominal owner of an $i$. was a god, represented by its temple. The ultimate control over the temple administration lay in the hands of the political authority ruling the city-state of Assur. The ownership is evident from expressions as "god, the $i$.'s owner $(b \bar{e} l), " 45$ or "the silver of the god." the $i$. is acknowledged by the frequent addition "of god so-and-so" $(s a \mathrm{DN})^{47}$. As pointed out by Hirsch and Garelli"is, not each of the gods attested in the so-called onomastic pantheon is also attested in cultic context. This means that several gods known from personal names are absent from the group of deities presently attested as $i$. owners. This last group includes *Adad, *Ašsur, Bēlum, Ilabrat, Išhara, *Ištar, Ninkarrak (but see note 18), Suen and Samaš, Šamǎs alone, Šarra-mātēn, Tašmētum, and perhaps Ana. The details available have been collected below in Appendix A. Those gods known to have possessed a temple in Assur during the Old Assyrian period are marked with an asterisk. Votive offerings are known to have been presented to Aššur, Ilabrat, Ishara, Ištar, and to Tašmētum. The names Bēlum and Šarra-mātēn have caused some discussion. The first, literally "lord", can be a mere epithet for an unnamed god, but it is also used to denote an independent deity ${ }^{49}$. The god here transcribed as Śarra-mātēn is generally considered to

45. TC 1, 26: ${ }^{35}$ DINGIR be-el $i k$-ri-bi li-ir-de $-k a^{2}$; TC 3, 88 contains an isolated reference to "god, owner of the silver" at the end of the text: ${ }^{36}$ "sa 1 ma-na KB $i$ š $q u$-lu. DINGIR- $l i{ }^{37}$ be-el KB (erasure) (end of the text).

46. $\mathrm{Kt} \mathrm{n} / \mathrm{K}$ 1189: 15-16: KB ša ilim, in line 5-6: KB ša ikribe.

47. C. Michel suggested to read sa-ni- $*_{i}$ in BIN 4, $91: 5$ (ša $i k-r i-b i$ ša ni-x I 1), and translated "des autres offrandes votives, "remarking that sa-ni-i was apparently a mistake for šaniütim (Innäya II no 7+ collation on plate 1). I think one probably has to read a divine name although it remains unclear which (perhaps $N i-k[\grave{a}-r a-a k] ?$ ).

48. La religion de l'Assyrie ancienne d'après un ouvrage récent, RA 56 [1962], $195 \mathrm{ff}$.

49. Hirsch, UAR, 22-23, note 113, and 13; Gareili, RA 56, 196. 
be Aššrur ${ }^{50}$. Bēlum and Šarra-mātēn both occur as $i$. owner in RA 59 no 5 , which indicates they cannot be considered to be epithets of the same god. Similarly, the gods named in connection with taphïrum (a fund to which traders made contributions) are Bèlum and Šarra-mātēn. While Bēlum might be an independent deity, Šarra-mātēn could denote Ašsur; why the texts prefer to name the head of the Assyrian pantheon by this epithet remains obscure. The volume of $i$. given by a temple was related to the hierarchical position of the god in the cultic pantheon. Even on the basis of the fragmentary evidence, Aššur clearly stands out as the most important provider of $i$. The relative position of the other deities in the pantheon remains unclear; one might deduce their relative importance from the quantities in texts where more than one $i$. occurs ( $\mathrm{g}=$ shekel; $\mathrm{m}=\mathrm{mina})$ :

$$
\text { kt e/k } 37^{51} \quad \text { BIN } 6,186^{52} \text { RA } 60 \text { no } 43^{53} \text { VS } 26,11^{54}
$$

Adad 40g silver

Aššur

Ilabrat

Išhārā $1 \mathrm{~m}$ silver

Ištar

Samaš $1 \mathrm{~m} 22 \mathrm{~g}$ gold + $2 \mathrm{~m} 22 \mathrm{~g}$ silver
3 kutānum (+ Mlabrat)

7 kutānum $2 r+1 s+2 k s \quad 3$ kutänum

1 kutānum $1 r$

1 šrum 1 kutānum

1 kutānum

50. J. Lewy, HUCA 27, 13-17 (cf Veenhof, VS 26, p.21 no 43); Garelli, $A C$ 327-329 and RA 56, 209 note 1; Hirsch, UAR, 26 and 14; W.G. Lambert, MARI 4. 529 note 4.

51. KL e/k 37: ${ }^{24} 1$ l/3 ma-na 2 GÍN KÙ.GI 252 ma-na 22 GÍN KB ša dUTU ${ }^{26} 1$ ma-na sa Is-ha-ra 2/3 ma-ma ${ }^{27}{ }^{20}{ }^{d} \mathrm{IM}$.

52. BIN 6, 186: ${ }^{4} \ldots .7$ TÚG $k u-t a-n u^{5} i k$-ri-bu ša A-sur 1 TÚG su-ru-um ${ }^{6} i k-r i-b u$ sadištar.

53. RA 60 no 43: ${ }^{18} 2$ TÚG ra-qá-ta-an ${ }^{19} 1$ TÚG ši-li-ip-ki-um 202 TÚG $k u$-sí-ta-an ${ }^{21} 1$ ma-na 4 GIN AN.NA ${ }^{22} a-n a$ qá-tim ša ik-ri-bi-a ${ }^{23} s a$ A-š̀ $I$ TÚG $k u-t a-n u m{ }^{24}{ }_{S} a$ ik-ri-bi ${ }_{4} a$ ša Ištar ${ }^{25} I$ TÚG ku-ta-nu ša $i k-r i-b i_{4}-a{ }^{2 \sigma_{s} a}$ WIN.ŠUBUR ${ }^{27} 1$ TÜG ku-ta-num ša ik-ri-bi $i_{4}-a^{28}[\check{s}] a^{d} U T U$.

54. VS 26, 11: ${ }^{16} 3$ [TÚG ku-t]a-nu $\}_{a} i k-r i-b i{ }^{4}{ }^{17}$ sa $A$-šùr 3 TÚG ku-ta-nu ${ }^{185}$ sa

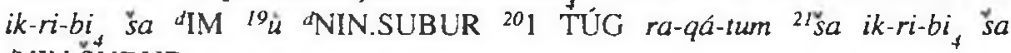
ANIN.ŠHBUR. 
We have to bear in mind that most references may concern only fractions of the $i$. Beyond this it is not known what the limits were to the volume of silver and gold a trader could hold as $i$. of one god.

I. silver belonging to Aššur is also mentioned in ICK 1, 17, where Narāmtum writes to Akitäya and Adad-bānī: "Who will pay the debt in your stead? Don't you know that here your brother(s) and your father owe silver to the House of the City? The (amount of) silver (due from) the agents has increased at the expense of that of Ašsur; you keep quiet and are not turning to the kärum while people are robbing you!"ss It remains difficult to assess whether the financial problems experienced by Püsu-kēn and involving both a divine and human creditors, mentioned in $\mathrm{BIN} 4,32$, are related to $i$. as Garelli has suggested ${ }^{56}$.

TC 1,101 (= EL 153) is atypical because a native god seems to be mentioned as creditor within the sphere of Assyrian merchants: “ $11-2$ 1/2 shekels of silver of my god (and) ${ }^{34} 4 / 2 / 3$ shekels of silver of Ana, ${ }^{5-7}$ I gave as tadmiqtum-loan to Ilī-bānī. ${ }^{8.9} 1 / 2$ mina of copper as his t. (ta-aq-ri-a-sú) (and) (ta-11 $^{1 / 3}$ mina (of copper) because of the one-fifth ${ }^{12 \cdot 13}$ I paid on his behalf ${ }^{14-15}$ two Assyrian witnesses)." Unless one has to emend $a$-na to $a-\check{s} u r !$, J. Lewy's interpretation of $a-n a$ as the divine name Ana is correct ${ }^{57}$. Ana is an Anatolian deity venerated by Assyrians as well, and his name occurs as a theophoric element in the Old Assyrian onomasticon ${ }^{58}$. At this point, one can only say that Assyrians (if the anonymous writer was indeed an Assyrian) could posess silver belonging to

55. ICK 1, 17b:23 ... hu-hu-lam ${ }^{24}$ ma-num i-ša-qal ${ }^{25} a-p u-h i-k u-n u$ a-na-kam ${ }^{26} k i-a m$ a-hu-ku-nu ì $a-b u-k u-n u{ }^{27} \mathrm{~KB}$ a-na É $a-l i m^{\text {ti }}{ }^{28 h a-b u-l u-\langle n i>l a ́}$

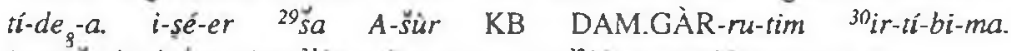

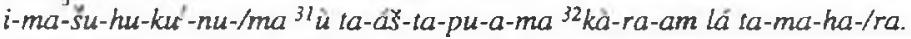

56. RA 59, 192 note 6. See Hirsch, UAR, 49-51, for other examples of silver or gold borrowed from gods. A debt of gold to Adad occurs also in kt a/k 447. Cf. Larsen, $A O C C, 314$ with note 76.

57. EL, p. 140 note c; also Larsen, OACC 383 , where the term "one-fifth" is discussed.

58. Hirsch, UAR, 27-28 and note 131. 
this specific deity; whether this was a loan similar to the ikribuinstitution known from Assur and Kanish must remain unclear. Lewy followed B. Lansberger's concept of a "minimal $i$." which a person in need would promise as a minimal offering to the deity who privided him with a loan. In his discussion of TC 1, 101, he read takribātum in line 9, and interpreted this as such a minimal $i$. (El, p. 140 note e). ${ }^{59}$

\section{The holders}

One holds an $i$., and although in the three cases known to me the subject of the verb "to hold" ( $\mathrm{ka}$ "ulum) is not the original holder of the $i$., apperently this was also the verb used in Assyrian. The persons known to have held an $i$. can be found Appendix B at the end of this article. They were usually the (male) head of a family, but within the family a father could hand over an $i$. to one or more of his children. This appears from text ICK 1, 12 which contains the will of $\Pi \bar{i}-b a ̄ n \overline{1}$, who was married to Lamassĩ, and whose children were Ahātum, a gubabtum-priestess, and two sons: Ia and Iküppia. Of interest are lines 37-41: "Ia and Ikūppia will do business with the 1 mina of silver of my $i$. which Ikupppia is holding, and they will take away from my daughter [(Ahātum)] my i. [of DN]." ${ }^{60}$ W. von Soden translated lines 40-41 "(I. and I.) werden sich verständingen ( $\left.i-m a-g u_{s}-r u-m a\right)$ und meine "Spenden" [hinbringen (?) ([ú?-bu?-lu?])]. [Ahătum] is meine Tochter; (nur) sie werden "wegnehmen".," As a trader would find no difficulty in paying back 1 mina of silver, he suggested that $i$. denotes here an offering for llì-bānī after his death C. Wilcke also derived the form in line 40 from magārum, but translated "to have free disposal of" (frei disponieren) ${ }^{62}$. The rest of line 40 and the translation are the same as I have given above. Wilcke rejected the idea that $i$. means

59. Von Soden booked it under taqribtum (AHw 1324a); however, the form ta-aq-ri-ba-tám in $\mathrm{kt}$ a/k 339: 37 reveals this word is rather taqribatum.

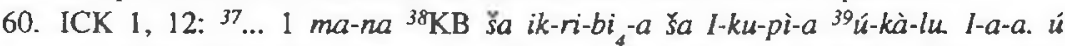
I-ku-pi-a ${ }^{40} i-m a-k u-r u-m a . \quad i k-r i-b i-a . \quad\left[\hat{s} a\right.$ DN (A-ha-tám)] ${ }^{41} m e-e r-i-t i$. šu-nu-ma. e-ki-mu.

61. Ein altassyrisches Testament, WdO 8 [1975-1976), 212-213.

62. Assyrische Testamente, ZA 66 [1976], 203. 
an offering to the gods(!) after the death of Ili-bänī, and suggested instead that the death had rendered the $i$. obsolete, so that they could now be used for other purposes, without however specifying which. In my opinion, von Soden and Wilcke both misinterpret lines $37-40 \mathrm{a}$, by understanding the verbal form as derived from magärum instead of the more obvious makärum, "to do business". This passage stipulates that after their father's death, Ikūppia will have to share with his brother the use of the 1 mina of their father's i. which Iküppia held during his father's lifetime and which he probably had been using for his own trade. The reason why Abātum has to give up the $i$. of her father she had been holding is unclear. It might be related to her status as gubabtum. Her father compensated her for this loss by making her creditor in his stead of three claims (lines 2-10).

Daughters holding an $i$. are mentioned in KTS 25a as well. This letter, last edited and translated by C. Michel (Innäya II no 253), was sent to Püsu-kēn by his sisters(?) Tarîš-mātum and Belatum. They relate how Puzur-Ištar's and Ușur-ša-Aššur's daughters (called şuhartum, "girl") became seriously ill. Suspecting a religious motive for the illness, they obtained a message from the god, according to which they had to take away (ekämum) immediately the $i$. from the girls. The women now ask Pusu-ken to obtain a decision from the girls' fathers ${ }^{63}$. If the answer is positive, they will take away the $i$. The reason for the god's anger might be the girls' inability to fulfil the obligations connected with holding an $i$. Hirsch, in his article on mazzäzum (WZKM 62, 55-58), argues that the girls are punished for a sin committed by Pušu-kēn: he would have given his father's $i$. money as a security. Hirsch bases this interpretation on TC 2, 21: 17-18, where he renders (ikribi ša abini) ú-ša-zi-zu" "(als Pfand) gestellt hat, "but I cannot follow his interpretation of izēzum $\breve{S}$ given there in note 24; "to give as a security" is expressed in OA by erābum $\check{S}$ or ana sapartim nadā'um. Püšu-kēn might instead have done something praiseworthy, if lines 16-20 are translated "And (as for) Püsu-kën,

63. That Ușur-ša-Aššur is one of the şuhārû is apparent from KTS 24: 20-28. 
who has taken great pains ${ }^{64}$ to make the $i$. of our father "stand" for our father's family: you ought to pay the gentlemen each time the equivalents (of his expenses) as compensation." ${ }^{65}$ I assume that $P$. is meant by awilam in line 19. Veenhof also considers the girls to be blameless; he regards the divine order as an attempt to punish the merchants by taking away from their relatives valuable items as compensation for what they owe ${ }^{6 s}$.

The meaning of the verb ekämum in this text and in ICK 1, 12:41 is not immediately clear. In ICK 1, 12, Ahātum's brothers will take the $i$. away from her, either to keep it themselves, though this is not stated in the text, or to return it to the god, which means the end of this particular $i$. - loan. In the second text, the $i$. of both girls have to be taken away by order of the deity who owned $i^{67}$. Also in this text, it remains unspecified who will receive the $i$. One might think of the girls' fathers, but it seems more probable that the women who will take it away are to return it to the god, and are in this way ending the obligation which caused so much nuisance.

There are more references to women holding an $i$. Lamassatum, the wife of the by then already deceased merchant Elamma, leaves on her death an amount of silver referred to as " $i$. of Elamma", which means she held and used this money after the death of her husband ( $\mathrm{kt} 91 / \mathrm{k} 421: 5-6$ ). It is unclear whether Šimat-Aššur, who according to ICK 2, 89 has to receive 11 minas of fine copper of $i$. of Aššur, or Lamassī receiving 20 minas of fine copper, being $i$. of Belum, from her husband Püšu-kēn (CCT 2,

64. Nê-um N with AHw, cf. CAD N II, 200a: litt. 'to be turned upside down.'

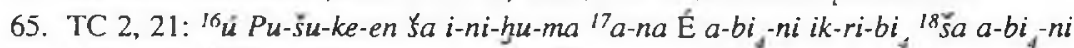
ú-ša-zi-zu-ü? ${ }^{19} a$-wi-lam me-eb-ra-tim ${ }^{201}$ ta-ta-na-pá-lá.

66. Schrijvend Verleden. 90. Cf. also K. van der Toom, Sin and Sancrion in Israel and Mesopotamia [1985], 78 with note 307 on page 199, and H. Avalos, Illness and Health Care in the Ancient Near East. The Role of the Temple in Greece, Mesopotamia, and Israel [1995], 132, 133.

67. This precludes the interpretation "to take away unlawfully" given for the verb in this text in CAD E, 65a. 
36a: 9-10), were also the persons holding it or merely the holder's wives. The reference in VS 26, 150 to textiles and their value belonging to the $i$. of Ašsur-mälik and to that of his wife and daughter, could indicate that these women held an $i$. as well ${ }^{68}$.

The case of joint holdership has already been discussed in ICK 1,12 , where two brothers will jointly hold an $i$. TC 3, 207, contains a reference to $i$. of "The house (=family) of Ilì-dān."69 Mention is made of 9 minas 29 shekels of tin of "our $i$ " in BIN $4,51 .^{70}$ In these cases the $i$. are all held jointly between members of one family, the writers and addressee of BIN 4, 51, Aššur-nădā, Ilî-ălum, and Aššur-taklāku, are the sons of Ašsur-iddi(n). On the other hand, there are many instances where an $i$. is connected to only a single individual, and is designated as "my $i$." or "the $i$. of PN" The second reference in the quote from BIN 4, 51, only mentions "the $i$.," without naming a specific holder. Apparently, this was clear enough to those concerned, and it was unnecessary to identify the holder, as it did not matter to outsiders who he was. Apart from a joint holding, individual members of a family could at the same time hold their own $i$., as in the case of Ašsur-iddi(n)'s sons (see Appendix B). In general, an $i$. was held by an individual on his own responsibility, but he was free to share it with members of his family.

The OA $i k r i b \bar{u}$ - system emerges from the textual material as a balanced attempt to promote trade and prosperity by making available temple funds for commercial purposes. The various temples in Assur received votive offerings which enhanced their

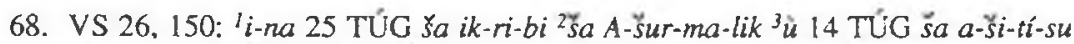
${ }^{4} \grave{u}$ me-er-i-ti-su... "3 GÚ 2 ma-ra ${ }^{12}$ AN.NA a-wi-tum ša "Ii]k-ri-bi sa

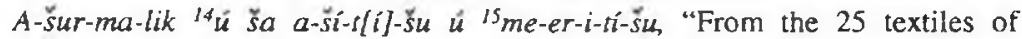
Aššr-mălik's $i$. and the 14 textiles of his wife and daughter (...) The value of Ašsur-mălik's $i$. and of that of his wife and daughter is 3 talents 2 minas of tin."

69. TC 3, 207: ${ }^{7} 4$ ma-na KÙ ša É Í-li-/dan ${ }^{8} 1 / 3$ ma-na Y̌a ik-ri-bi-š-su-/nu.

70. BIN 4, 51: ${ }^{59 / 13}$ ma-na 9 GÍN ${ }^{6}$ AN.NA sa $i k-r i-b i{ }_{4}-n i{ }^{7} 34$ 1/3 ma-na AN.NA sa $i k-r i-b i_{4}{ }^{8} s a a-b a-a t u \dot{u}-b i_{4}-i l_{5}$. 
wealth and status. To the merchant and his family, an $i k r i b \vec{u}$ constituted a credit on very attractive conditions. The covert obligation to present valuable offerings to the god as a token of gratitude confirmed his social status as a respectable member of the community: as an awilum.

\section{Appendix A}

The evidence of silver, gold, copper, and merchandise mentioned as belonging to the $i$. of a specific deity ("transport" includes packages given for safekeeping) is:

Adad

silver: $40 \mathrm{~g}$, kt e/k 37: 26-27

unspecified amount of silver and gold, $i$. of Aššur and Adad, kt c/k 50: 35

merchandise:

3 kutānum (Adad together with Ilabrat), VS 26, 11 : 17-19.

Aššur

gold: Im pašallum, TC 3, 68: 3-5 (transport)

silver: $\quad 11 / 2 \mathrm{~g}, \mathrm{RA} 59$ no 13: 13-15 (gift?)

$20 \mathrm{~g}, \mathrm{kt}$ a/k 495b (tadmiqtum-loan)

24g, kt m/k 116: 1-3 (loan)

30g, kt 9l/k 366: 38 (transport); KUG 28: 4-5

(transport)

$30+x$ g, kt d/k 3: 1-3 (loan)

$35 \mathrm{~g}, \mathrm{KUG} 28: 11-12$ (transport)

$45 \mathrm{~g}, \mathrm{kt} 87 / \mathrm{k} 38: 1-3$

4m, CCT 1, 21c: 4-7 [Ulshöfer, $A P$ no 422]

$15 \mathrm{~m}, \mathrm{CCT} 1,16 \mathrm{~b}: 4-5$ (transport)

copper: 11 minas of fine copper, ICK 2, 89: 1-2 (transport) 
merchandise:

2 raqqatum +1 silipkium +2 kusitum, RA 60 no 43:

18-23

3 kutänum, VS 26, 11: 16-17

4 kutānum, TC 1, 80: 26-28; TC 1, 80: 29-31

7 kutānum, BIN 6, 186: 4'-5'

textiles unspec.: BIN 6, 30: 26-27; KTS 22a: 13-14

$15 \mathrm{~m}$ tin, VS 26, 65: 40 (riksum)

Bèlum

gold: $\quad 1 \mathrm{~m}, \mathrm{LB} 1220: 12-13$

silver: $\quad \log$, TC $3,207: 27-28$; TC 3, 207: 29-30

30g, 1 736: 20-21

copper: 20m, RA 59 no 5: 11-12 (transport)

20m of fine copper, CCT 2, 36a: 9-10 (transport)

Ilabrat

merchandise:

1 raqqatum, VS $26,11: 20-21$

1 textile, TC 3, 96: 10-11

1 kutānum, RA 60 no 43: 25-26

3 kutänum, VS 26, 11: 17-19 (Adad+Ilabrat)

Ishara

silver: $\quad 6 \mathrm{~g}, \mathrm{RA} 59$ no 24: 6-7 (transport)

15g, RA 59 no 24: 5 (transport)

$1 \mathrm{~m}, \mathrm{kt} \mathrm{e} / \mathrm{k} 37: 26$ (transport)

Ištar

1 šurum, BIN 6, 186: 5'-6'

1 kutānum, TC 1, 80: 31-32: RA 60 no 43: 23-24

Ninkarrak

copper: $\quad 3 m$ (read $30 ! m$ ?) of fine copper, TC 2, 54: $8^{\prime}$

(transport) 
Suen and $\check{S} a m a \check{s}$

1 šitrum-textile, kt 91/k 372: 6-8

Šamaš

gold: $\quad 1 \mathrm{~m} \mathrm{22g,} \mathrm{kt} \mathrm{e/k} \mathrm{37:24} \mathrm{(transport)}$

silver: $\quad 5 \mathrm{~g}, \mathrm{TC} 3,207: 30-31$

$2 \mathrm{~m} 22 \mathrm{~g}$, kt e/k 37: 25 (transport)

Šarra-mātên

silver: $\quad 15 \mathrm{~g}$, RA 59 no 5: 8-9 (transport)

\section{Tašmētum}

gold: $\quad$ an object weighing $3 \mathrm{~g}, \mathrm{kt} \mathrm{m} / \mathrm{k} \mathrm{1:} 20-22$

silver: $\quad 5 \mathrm{~m} 20 \mathrm{~g}, \mathrm{kt} \mathrm{m} / \mathrm{k} 1: 20$

$$
\begin{gathered}
\text { Appendix } B \\
\text { Known ikribü-holders } \\
(\mathrm{g}=\text { shekel, } \mathrm{k}=\text { kutānum-textile; } \mathrm{m}=\text { mina; } \mathrm{t}=\text { talent })
\end{gathered}
$$

- Ah-šalim son of Buzutāya, kt 87/k 342 (1m of $i$. gold); 386 ( $1 \mathrm{~m}$ of $i$. silver given as tadmiqtum); 459 (11 textiles bought with $1 \mathrm{~m}$ of $i$. silver).

- Ahātum daughter of Ilī-bānī, see Ilī-bānī son of Ia.

- Alāhum, kt c/k 454 (40 textiles); kt c/k 50 (i. of Aššur and Adad).

- Alāhum (different person?), KTS 9b (11m of silver); TC 3 , 271 (silver, gold, and cups of his $i$.)

- Amur-ilï, CTMMA 1, 79 and TC 1, 19 (i. textiles).

- Amur-Ǐstar, BIN 4, 113 (i.k.'s); RA 59, 24 (15g+6g, i. of Išnthara, sealed by A.).

- Amurru-banī, KTK 15 (7 k.'s).

Ǎšsur-iddi(n) son of Suli (and father of Ašsur-nada and 
Aššrur-taklaku), kt e/k 37: 36 (1m 42g); BIN 6, 30 (190 textiles, $i$. of Aššur, sun disc of $15 \mathrm{~g}$ of gold pledged to Ilabrat; Pa. 10 and CCT 4, 2a (sun disc of $1 \mathrm{~m}$ of gold pledged to Aššur; $6 \mathrm{~m}$ of silver for Ištar); Pa. 13 (1t of tin); TC 1, 80: 20-22 (k k.'s i. of Aššur; $2 i$. of Ištar); VS 26, 11 (3k. 's $i$. of Aššur; 3 (1t of tin); TC 1, 80:20-22 ( $4 k$. 's, $i$. of Aššur; $2 i$. of Ištar); VS 26,11 ( $3 k$. 's $i$. of Aššur; $3 k$.'s $i$. of Adad and of Ilabrat; 1 thin textile $i$. of Ilabrat).

Aššrur; 3 k.'s i. of Adad and of Ilabrat; 1 thin textile i.of

-Ǎšsur-imittī, KTS 22a (textiles of $i$. of Aššur); TC 3, 85 (i. ša ilim); concerning the debt to the bët älim after his death: $\mathrm{kt} \mathrm{n} / \mathrm{k} 115$; 286 and 445 ( $11 \mathrm{~m}$ of $i$. silver); 531; 1189.

- Ašsur-kašid, TC 3, 96 ?

- Ašsur-mālik (father of Enlil-bänī), concerning his inheritance: TC 1,3 (merchandise worth $30 \mathrm{~m}$ of silver of A.'s $i$.); VS 26,150 (25 textiles of A.'s $i$. together with 14 of A.'s wife and daughter).

- Aššur-nādā son of Aššur-iddi(n), KUG 28 and TC 1, 80: 26-28 (1/2 m of silver of his $i$. of Ašsur used to buy $4 k$.'s).

- Aššur-nâdā son of A.šsur-iddi(n) and his brother Aššur-taklāku, BIN 4, 51, (15 Akkadian textiles, 18 k.'s, 1 donkey, and $9 \mathrm{~m} 29 \mathrm{~g}$ of tin from "our" $i$.).

- Aššur-taklāku son of Aššur-iddi(n), KUG 28 and TC 1, 80: 29-32 (sends 35g of silver of $i$. of Aššur, $4 k$.'s of $i$. of Ašsur and 1 of $i$. of Istar brought to him).

- Buzāzu son of Pūšu-kēn, CCT 2, 32a (1m 35g of gold and $1 / 2 \mathrm{~m}$ of gold of his $i$., first amount for purchase of textiles, $i$. for that of tin).

- Elamma, kt 91/k 530 (5g of silver given to PN). Kt 91/k 421 (list of assets left by Lamassatum, E.'s wife, upon her death. One entry concerns " $25 \mathrm{~g}$ of silver sealed by me, $i$. of E.," which suggests Lamassatum had survived her husband). 
- Enlil-bānī (son of Aššur-malik?), BIN 6, 31 (5m of silver of E.'s $i$.); TC 3, 68 (1 $\mathrm{m}$ of gold).

- Ennam-Aššur son of Elamma, kt 91/k 290, 366, 407, and 505 $(1 \mathrm{~m} 14 \mathrm{~g}$ of silver $+1 / 2 \mathrm{~m}$ of silver of his $i$. of Ašsur, to make purchases with).

- Hināya, kt 91/k 329 and kt m/k 91 (3 textiles, valued at $10 \mathrm{~g}$ of silver each); $\mathrm{kt} \mathrm{m} / \mathrm{k} 80$ ( $13 \mathrm{~m}$ of silver).

-Iddi(n)-Suen, VS 26, 61 (amütum-iron of his $i$.).

- Ikūppia and Ia sons of Ilī-bānī, see Ilì-bānì son of Ia.

- Ilabrat-bānī, kt n/k 210 (gold of his i.).

- Ilī-älum, RA 60 no 43 (i. of Aššur: 2 thin textiles, 1 silipkium, 2 kusītu's; $i$. of Ištar: $1 k$.; $i$. of Ilabrat and Šamaš: $1 k$.).

- Illi-bānì son of Ia, ICK 1, 12 (his sons Ia and Iküppia will do business with $1 \mathrm{~m}$ of silver of his $i$. currently held by Ikuppia. His $i$. being held by his daughter Ahātum must be taken away from her by her brothers, to be returned to the divine owner?).

- Ilī-nādā, BIN 4, 3 (1 $\mathrm{m}$ of silver).

- Imdilum son of $\breve{S} \bar{u}$-Laban, I 607 (Ennam-Belum received 2 fine $k$.'s from I.'s $i$. as tadmiqtum); concerning $i$. textiles entrusted to Adada: Medelhavsmuseet 1977/12 (82 textiles brought), CCT 2, 11, KTS 19b (read in line 9: A- [da-d]a).

- Innāya, BIN 4, 91 [Michel, Innäya II no 7] (about a riksum); kt $87 / \mathrm{k} 34$ (riksum with $10 \mathrm{~m}$ of silver).

- Pusu-kēn son of Suea, LB 1219 (i. gold used to buy merchandise); JCS 14 no 4 (299 k.'s of P.'s i.); CCT 2, 36a: 9-10 (20m of fine copper, $i$. of Bēlum); TC 3, 35: 15-17 (ikribum pledgeg to Tašmëtum). 
- Puzur-Aššur, TC 3, 171 [Ulshöfer, AP no 190] (6m 4g of silver).

- Śalim-ahum, AKT 3, 65 (7m of tin, for which silver at a rate of 1:7 must be sent to him); AKT 3, 73 and 74 (S. asks Dān-Ašsur to bring the silver of S.'s $i$., which he will not use for making purchases, but will bring into the temple); KTS 27b (Püsu-kēn has to send $15 \mathrm{~m}$ of $i$. silver or the equivalent in gold); TC 2,4 (Püsu-kēn must send $1 \mathrm{~m}$ of gold for S.'s i.); concerning Ilabrat-bänī: CCT 2, 3, Pa. 7, and TC 1, 26 (1 white kusitum-garment and 3 other textiles from S.'s $i$. He has to pay $1 \mathrm{~m}$ of silver (Pa. 7), and Š. asks Püšu-kēn to use his own silver to reach the amount of $1 \mathrm{~m}$ because of "the god" (TC 1, 26: 32-33).

- $\breve{S} \bar{u}$-Hubur, VS 26, 65 and KTS 21 b (15m of tin, $i$. of Ašsur).

- $\check{\text { Su-}}$-Ľstar, kt u/k 3 (16 textiles).

This article was written as part of the project "The Economy of Ancient Mesopotamia", funded by the Netherlands Organization for Scientific Research (NWO). I am grateful to the following persons for permission to use texts they are preparing for publication: K. Hecker (I; kt $\mathrm{m} / \mathrm{k}$ and $\mathrm{kt} 87 / \mathrm{k}$ ); Y. Kawasaki (kt 89/k); K.R. Veenhof (LB; kt 9l/k).

Note that the name of divine Assur is written Assur, while that of the city is rendered Assur. To avoid unecessary repetitions, I give here the references to some kt texts: $\mathrm{kt} \mathrm{c} / \mathrm{k} 50$ ) published in AMMYıllı̆̆ 1990, 105; kt e/k 37: published in AMMYlllı̆̆ 1993 , 52; kt u/k 3:a photograph of the tablet was published by T. Özgüç, Kültepe-Kanis II, plate la-b. 